University of Tennessee Law

Legal Scholarship Repository: A Service of the Joel A. Katz Library

UTK Law Faculty Publications

$1-2020$

\title{
The United States International Religious Freedom Act, Nonstate Actors, and the Donbas Crisis
}

Robert Blitt

Follow this and additional works at: https://ir.law.utk.edu/utklaw_facpubs

Part of the Law Commons

\section{Recommended Citation}

Blitt, Robert, "The United States International Religious Freedom Act, Nonstate Actors, and the Donbas Crisis" (2020). UTK Law Faculty Publications. 167.

https://ir.law.utk.edu/utklaw_facpubs/167

This Article is brought to you for free and open access by Legal Scholarship Repository: A Service of the Joel A. Katz Library. It has been accepted for inclusion in UTK Law Faculty Publications by an authorized administrator of Legal Scholarship Repository: A Service of the Joel A. Katz Library. For more information, please contact eliza.boles@utk.edu. 


\title{
THE UAVERSIYY OF TENNESSEE KNOXVILLE
}

\section{Research Paper \#392}

June 2020

\section{The United States International Religious Freedom Act, Nonstate Actors, and the Donbas Crisis (Abstract Only)}

\author{
Robert C. Blitt \\ Do not cite without author's permission \\ Copyright (C) 2020 \\ This paper may be downloaded without charge \\ from the Social Science Research Network Electronic library at \\ http://ssrn.com/abstract $=\mathbf{3 5 2 1 9 0 9}$
}

Learn more about the University of Tennessee College of Law: law.utk.edu 


\title{
The United States International Religious Freedom Act, Nonstate Actors, and the Donbas Crisis
}

\author{
Elizabeth A. Clark \& Dmytro Vovk, eds., Religion During the Russian Ukrainian Conflict \\ (Routledge, 2019) \\ Posted: 17 Feb 2020 • Last Revised: 02 Mar 2020
}

\section{Robert C. Blitt}

University of Tennessee College of Law

Date Written: January 18, 2020

\section{Abstract:}

This chapter explores whether recent changes to the International Religious Freedom Act (IRFA) furnish the U.S. government with effective tools for engaging with and taking potential action against nonstate actors, such as the self-proclaimed Donetsk People's Republic (DPR) and the Luhansk People's Republic (LPR), operating in the context of the Donbas crisis. Among the major amendments to IRFA introduced at the end of 2016, the statute now provides the U.S. government with the formal obligation to report on violent nonstate actors (NSAs) found to be violating freedom of religion or belief. In addition, the executive branch may designate those NSAs found to be violating freedom of religion in a "particularly severe" manner as "entities of particular concern" (EPCs). This framework-which in certain respects mirrors IRFA's treatment of designated "Countries of Particular Concern" - also opened the possibility for the president to act against EPCs, including the imposition of sanctions.

One might reasonably assume that Congress' decision to supplement IRFA with NSA-specific provisions would enhance the executive's ability to confront NSA-based violations of freedom of religion or belief. However, an examination of the first sets of EPC recommendations and designations from 2017 and 2018 put forward by the U.S Commission on International Religious Freedom (USCIRF) and the State Department indicates that IRFA's capacity to successfully respond to such violations is being hampered by both statute-based and implementation-related challenges. These challenges are equally evident in the context of the Donbas conflict, and in turn underscore serious questions regarding the relevancy and effectiveness of IRFA's NSA provisions. 